\title{
Peramalan Kapasitas Baterai Lead Acid pada Mobil Listrik Berbasis Levenberg Marquardt Neural Network
}

\author{
(Prediction Capacity of Lead Acid Battery on Electric Vehicle Based Neural Network Levenberg)
}

\author{
Mambak Udin, Bambang Sri Kaloko, Triwahju Hardianto \\ Jurusan Teknik Elektro, Fakultas Teknik, Universitas Jember (UNEJ) \\ Jln. Kalimantan 37, Jember 68121 \\ E-mail:udinmambak@gmail.com
}

\begin{abstract}
Abstrak
Salah satu pembahasan dalam penelitian mobil listrik adalah sumber energi atau baterai. Baterai pada mobil listrik mempunyai kapasitas yang terbatas sehingga harus dilakukan pengisian ulang agar mobil listrik tetap bisa berjalan jauh. Keadaan ini bila tidak segera diatasi bisa menyebabkan baterai tiba - tiba habis ditengah jalan. Tentu hal ini membuat cemas dan tidak nyaman bagi pengguna mobil listrik. Oleh karena itu diperlukan peramalan kapasitas baterai agar diketahui kapan waktunya untuk mengisi ulang baterai atau bahkan menggantinya. Penelitian ini membahas peramalan kapasitas baterai mobil listrik berbasis kecerdasan buatan levenberg marquardt neural network, serta membandingkan dengan sistem recurrent neural network. Kondisi mobil listrik menggunakan tiga kondisi beban yaitu kecepatan maksimal, akselerasi awal, dan tanjakan. Hasil penelitian menunjukkan peramalan sisa kapasitas baterai saat kecepatan maksimal setelah pemakaian selama 30 menit, sisa kapasitas baterai yang dapat digunakan diramalkan dengan backpropagation sebesar 61 Ah, dengan recurrent sebesar 60,5 Ah. Sedangkan target kapasitas sebesar 59,6 Ah. Sehingga metode terbaik dalam meramalkan kapasitas baterai adalah menggunakan recurrent neural network.
\end{abstract}

Kata Kunci: Baterai lead acid, levenberg marquardt, mobil listrik, neural network, peramalan.

\section{Abstract}

One of the discussion in the research of electric vehicle is the energy source or battery. Batteries in electric vehicle have limited capacity so it must be done so that recharging of electric vehicle can still walk away. This situation if not resolved could cause the battery suddenly depleted middle of the road. Of course this makes anxious and uncomfortable for users of electric vehicle. Therefore, it is necessary forecasting capacity of the battery in order to know when it's time to recharge the battery or replace it. This paper discusses the forecasting capacity of electric car batteries Levenberg Marquardt based artificial intelligence neural network, and compares with a recurrent neural network system. Conditions electric vehicle using three load conditions, namely the maximum speed, the initial acceleration and greadeability. The results showed forecasting the remaining battery capacity when the maximum speed for 30 minutes after consumption, the remaining battery capacity that can be predicted by the propagation method is $61 \mathrm{Ah}$, with recurrent amounted to 60.5 Ah. While the target capacity is $59.6 \mathrm{Ah}$. So the best method of predicting the battery capacity is using recurrent neural network.

Keywords: Electric vehicle, forecasting, lead acid batteries, levenberg marquardt, neural network.

\section{PENDAHULUAN}

Mobil listrik pada saat ini menjadi pembicaraan banyak orang dan sangat populer. Hal ini dikarenakan mobil listrik mempunyai beberapa keuntungan seperti efisiensi yang tinggi, tingkat pencemaran lingkungan yang rendah, tingkat kebisingan yang rendah, energinya tersedia dari berbagai sumber energi alternatif, mudah perawatannya, dan regeneratif. Mobil listrik lebih hemat energi dibandingkan dengan mobil berbahan bakar fosil konvensional [1].

Namun, jumlah mobil listrik yang ada di dunia masih jauh dibandingkan dengan mobil konvensional. Di Indonesia, mobil listrik masih dalam tahap pengembangan dan penelitian. Salah satu pembahasan dalam penelitian mobil listrik adalah sumber energi atau baterai. Jenis baterai yang digunakan pada mobil listrik bermacam-macam, seperti baterai lead acid, lithium ion, nikel cadmium, nikel metal hydride dan lain-lain. Jenis baterai sangat berpengaruh pada kapasitas energinya karena perbedaan karakteristik yang dimiliki oleh baterai. Kapasitas dari sumber energi merupakan parameter utama dari penyusun sebuah mobil listrik [2]. Baterai pada mobil listrik mempunyai kapasitas yang terbatas sehingga harus dilakukan pengisian ulang agar mobil listrik tetap bisa berjalan jauh. Keadaan ini bila tidak segera diatasi bisa menyebabkan baterai tiba - tiba habis ditengah jalan. Tentu hal ini membuat cemas dan tidak nyaman bagi pengguna mobil listrik. Oleh karena itu diperlukan peramalan kapasitas baterai agar diketahui kapan waktunya untuk mengisi ulang baterai atau bahkan menggantinya.

Peramalan kapasitas baterai mobil listrik telah diteliti oleh Chew Kuew Wai dalam jurnalnya, namun dalam peramalannya hanya menggunakan simulasi secara kisaran dinamis tanpa menggunakan kecerdasan buatan. Sedangkan penelitian yang dilakukan oleh Jie Liu sudah menggunakan sistem kecerdasan kendali neural network. Namun dalam penelitiannya hanya menggunakan baterai lithium ion dengan kapasitas kecil dan belum diaplikasikan dalam 
obyek nyata seperti mobil listrik yang memperhatikan berbagai kondisi jalan. Serta dalam meramalkan menggunakan metode resistansi internal (hambatan elektrolit dan hambatan transfer pengisisan) dan suhu. Sedangkan dalam mobil listrik metode tersebut tidak mudah untuk diterapkan.

Penelitian ini membahas peramalan kapasitas baterai mobil listrik dengan berbagai kondisi beban dan menggunakan sistem kecerdasan buatan neural network. Peramalan yang dilakukan menggunakan metode open circuit voltage (OCV) dan metode discharge yang mudah diterapkan dalam mobil listrik.

\section{TINJAUAN PUSTAKA}

\section{Mobil Listrik}

Mobil listrik adalah mobil yang digerakkan dengan motor listrik, menggunakan energi listrik yang disimpan dalam baterai atau tempat penyimpan energi lainnya. Prinsip kerja mobil listrik adalah input pengendali diperoleh dari pedal akselerator dan rem. Pengendali ini menyediakan sinyal yang sesuai ke konverter daya elektronika yang mengatur aliran daya antara motor listrik dan baterai. Motor juga memainkan peran generator, yang mengkonversi energi pengereman menjadi elektron dan mengisi baterai. Unit manajemen energi, bekerja sama dengan pengendali mobil, mengendalikan pengereman regenerasi dan rekoveri energi. Motor listrik menghasilkan torsi yang besar dari keadaan mobil berhenti. Hal ini menghasilkan kinerja yang sangat bagus. Percepatan dan daya mobil listrik jauh melampaui mobil mesin pembakaran dalam [3].

Kinerja dari sebuah mobil listrik biasanya digambarkan menjadi 3 model kondisi yang dirumuskan sebagai berikut [4].

1. Kecepatan maksimum menjelajah (Maximum Cruising Speed).

Kecepatan maksimum kendaraan didefinisikan sebagai kecepatan menjelajah konstan dimana kendaraan dapat menopang dengan beban penuh di jalan datar. Saat kendaraan melaju pada kecepatan maksimum, daya mekanik yang dibutuhkan dirumuskan sebagai berikut:

$$
\mathrm{P}=\left(\mathrm{frr} . \mathrm{m} \cdot \mathrm{g}+\rho \cdot \mathrm{A} \cdot \mathrm{Cd} \cdot \mathrm{V}^{2}\right) . \mathrm{V}
$$

2. Tanjakan (Gradeability)

Daya mekanik yang dibutuhkan pada mobil listrik selama tanjakan diperoleh dari rumus sebagai berikut:

$\mathrm{P}=\mathrm{m} \cdot \mathrm{g} \cdot \beta$. V

Dimana: $\beta$ adalah koefisien tanjakan (gradeability coefficient)

\section{Akselerasi awal (Initial Acceleration)}

Saat akselerasi awal, daya mekanik yang diminta oleh kendaraan dapat dirumuskan sebagai berikut:

$\mathrm{P}=\left(\mathrm{m} . \mathrm{g} . \mathrm{frr}+\rho . \mathrm{Cd} . \mathrm{A} \cdot \mathrm{V}^{2}+\mathrm{m}\right) . \mathrm{V}$.

Dimana: $\mathrm{P}$ adalah daya mekanik dalam watt; $\mathrm{m}$ adalah massa kendaraan dalam kg; g adalah percepatan gravitasi $\left(9,81 \mathrm{~m} / \mathrm{s}^{2}\right)$; frr adalah hambatan putaran ban (rolling resistance coefficient); $\rho$ adalah kerapatan udara (air density) $\left(1,202 \mathrm{~kg} / \mathrm{m}^{3}\right) ; \quad \mathrm{Cd}$ adalah koefisien aerodinamis (Aerodynamics Drag Coeffiient); A adalah luasan area depan kendaraan; dan $\mathrm{V}$ adalah kecepatan kendaraan dalam $\mathrm{m} / \mathrm{s}$.
Pada kendaraan bermotor, hubungan hubungan torsi terhadap daya dirumuskan dengan persamaan berikut:

$P=\tau \times \omega$

Dimana: $\mathrm{P}$ adalah daya dalam watt; $\tau$ adalah torsi dalam $\mathrm{Nm}$; $\omega$ adalah kecepatan sudut dalam radian per detik.

Sedangkan untuk motor listrik, rumusan untuk kecepatan sudut adalah :

$\omega=2 \pi \mathrm{n} / 60$

dimana: $n$ adalah kecepatan putaran motor (rpm).

\section{Kapasitas Baterai}

Kapasitas baterai menggambarkan sejumlah energi maksimum yang dapat dikeluarkan dari sebuah baterai dengan kondisi khusus tertentu. Tetapi kemampuan penyimpanan baterai dapat berbeda dari kapasitas nominalnya, diantaranya karena kapasitas baterai bergantung pada umur dan keadaan baterai, parameter charging dan discharging, dan temperatur. Satuan dari kapasitas baterai ini sering dinyatakan dalam Ampere hours, ditentukan sebagai waktu dalam jam yang dibutuhkan baterai untuk secara kontinu mengalirkan arus atau nilai discharge pada tegangan nominal baterai [5].

Metode yang dapat digunakan untuk mengetahui kondisi kapasitas baterai, adalah [6]:

1. Metode densitas cairan listrik, tetapi metode ini tidak cocok untuk Valve Regulated Lead Acid Battery (VRLA). Metode ini menggunakan pengukuran berat jenis cairan pada baterai untuk mengetahui sisa kapasitas suatu baterai. 2. Metode Open circuit voltage (OCV). Metode ini cocok untuk baterai baru, tetapi ketika baterai digunakan setelah waktu yang lama, dan kapasitas baterai turun, perubahan tegangan rangkaian terbuka tidak dapat mencerminkan keadaan sebenarnya dari kapasitas.

3. Metode discharge, kurva baterai diperoleh dengan eksperimen discharge dengan keakuratan dapat menggambarkan kinerja baterai. Namun, tes discharge tidak dapat sering dilakukan karena akan mempengaruhi kehidupan pelayanan baterai.

4. Metode resistensi internal, kurva resistansi - kapasitas baterai harus diukur dalam metode ini. Proses pengukuran rumit, sehingga keumuman dari metode ini adalah lemah.

\section{Backpropagation}

Backpropagation merupakan salah satu dari beberapa metode yang digunakan dalam neural network dan yang paling sering digunakan dalam berbagai bidang aplikasi, seperti pengenalan pola, peramalan dan optimisasi. Hal ini dikarenakan metode ini menggunakan pembelajaran yang terbimbing. Pola masukan dan target diberikan sebagai pasangan data. Bobot-bobot awal dilatih dengan melalui tahap maju untuk mendapatkan error keluaran yang selanjutnya error ini digunakan dengan tahap mundur untuk memperoleh nilai bobot yang sesuai agar dapat memperkecil nilai error sehinggga target keluaran yang dikehendaki tercapai.

Tujuan dari model ini adalah untuk mendapatkan keseimbangan antara kemampuan jaringan mengenali pola yang digunakan selama proses pelatihan berlangsung serta kemampuan jaringan memberikan respon yang benar terhadap pola masukan yang berbeda dengan pola masukan selama pelatihan [7]. 


\section{Recurrent Neural Network}

Recurrent neural network adalah neural network dengan fasilitas umpan balik menuju neuron itu sendiri maupun neuron yang lain, sehingga aliran informasi dari masukan mempunyai arah jamak. RNN adalah jaringan yang mempunyai minimal satu feedback loop. Feedback loop mempengaruhi kemampuan belajar dan kinerja jaringan. RNN memiliki kemampuan penggambaran yang sangat bagus dan dapat mengatasi kelemahan feedforward. Keluaran RNN tidak hanya bergantung pada masukan saat itu saja, tetapi juga tergantung pada kondisi masukan neural network untuk waktu lampau. Kondisi ini dimaksudkan untuk menampung kejadian lampau diikutkan pada proses komputasi. Hal ini penting untuk masalah yang cukup rumit, dan tanggapan keluaran neural network berkaitan dengan variasi waktu (time-varying), sehingga neural network memiliki kepekaan terhadap waktu dengan memori kondisi lampau [8].

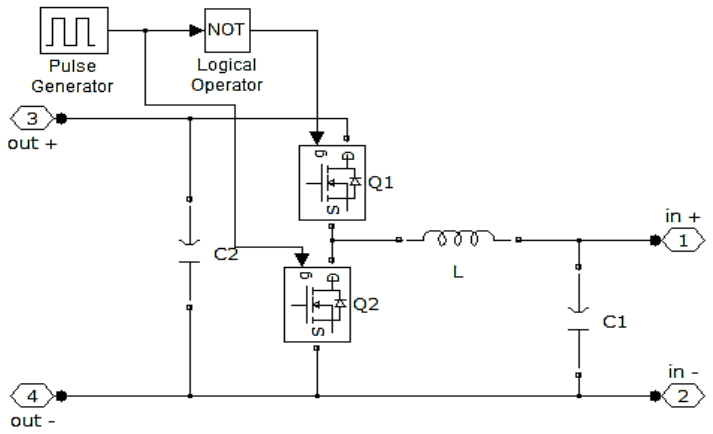

Gambar 1. Rangkaian Bidirectional DC-DC Converter.

Tabel 1. Spesifikasi Baterai

\begin{tabular}{cc}
\hline Jenis & $\begin{array}{c}\text { Lead } \\
\text { acid }\end{array}$ \\
\hline $\begin{array}{c}\text { Tegangan } \\
\text { Nominal }\end{array}$ & $12 \mathrm{~V}$ \\
\hline Kapasitas & $70 \mathrm{Ah}$ \\
\hline
\end{tabular}

Tabel 2. Spesifikasi Mobil Listrik

\begin{tabular}{lc}
\hline Massa Kendaraan $(\mathrm{Kg})$ & 200 \\
\hline Kecepatan maksimum $(\mathrm{m} / \mathrm{s})$ & 16,667 \\
\hline Kecepatan tanjakan $(\mathrm{m} / \mathrm{s})$ & 7 \\
\hline Kecepatan akselerasi $(\mathrm{m} / \mathrm{s})$ & 11,111 \\
\hline Gravitasi $\left(\mathrm{m} / \mathrm{s}^{2}\right)$ & 9,81 \\
\hline Rolling Resistance Coeffiient $(\mathrm{frr})$ & 0,013 \\
\hline Air Density $\left(\mathrm{Kg} / \mathrm{m}^{3}\right)$ & 1,202 \\
\hline Aerodynamics Drag Coeffiient $(\mathrm{Cd})$ & 0,29 \\
\hline Front Area of the Vehicle $\left(\mathrm{m}^{2}\right)$ & 2,13 \\
\hline Koefisien tanjakan pada sudut $30^{0}$ & $\mathrm{Sin} 30^{0}$ \\
\hline
\end{tabular}

\section{Levenberg Marquardt}

Algoritma levenberg marquardt merupakan pengembangan dari algoritma error backpropagation. Algoritma ini dibangun untuk mengatasi beberapa kekurangan yang ada pada algoritma error backpropagation dengan memanfaatkan teknik optimisasi numerik standar yaitu menggunakan pendekatan matriks Jacobian. Tujuan dari levenberg marquardt adalah meminimalkan total error [7]. Algoritma levenberg marquardt dirancang secara khusus untuk meminimalisasi galat jumlah kuadrat. Algoritma ini akan memperbarui bobot dengan cara memperkecil nilai galat dari selisih bobot baru dengan bobot lama. Namun, pada saat yang bersamaan, algoritma ini akan mempertahankan step size agar tidak menjadi besar [9]. Persamaan matematika untuk menentukan bobot baru pada algortima levenberg marquardt ialah sebagai berikut:

$$
\mathrm{w}_{\text {new }}=\mathrm{w}_{\text {old }}-\left(\mathrm{Z}^{\mathrm{T}} \mathrm{Z}\right)^{-1} \mathrm{Z}^{\mathrm{T}} \epsilon\left(\mathrm{w}_{\mathrm{old}}\right) \text {..... }
$$

dimana : $\mathrm{W}_{\text {new }}$ adalah bobot baru; $\mathrm{w}_{\text {old }}$ adalah bobot lama; $\epsilon$ adalah vektor galat; dan $\mathrm{Z}$ adalah matriks yang anggotanya adalah hasil diferensiasi galat terhadap bobotnya.

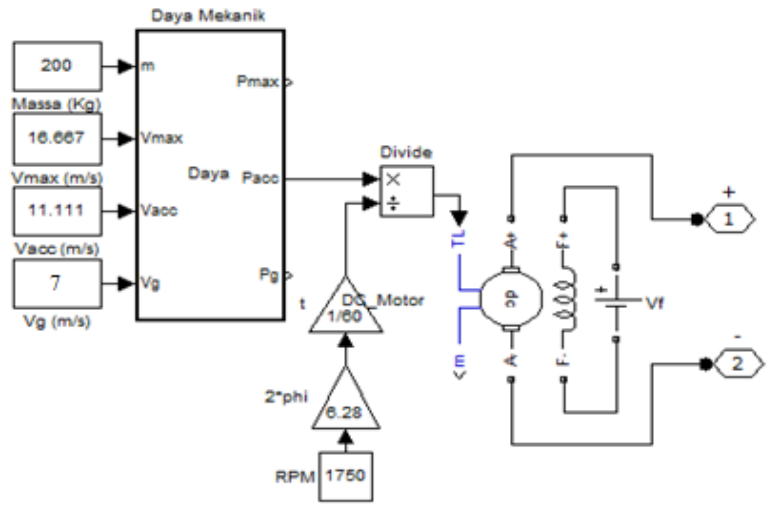

Gambar 2. Permodelan mobil listrik

Tabel 3. Kebutuhan daya mekanik

\begin{tabular}{cc}
\hline Kondisi & Daya (watt) \\
\hline Kecepatan maksimum menjelajah & 3863 \\
\hline Tanjakan & 6867 \\
\hline Akselerasi & 3524 \\
\hline \multirow{2}{*}{ Tabel 4. Torsi motor listrik } \\
\hline \multirow{2}{*}{ Kondisi } & Torsi \\
& (Nm) \\
\hline Kecepatan maksimum menjelajah & 21,09 \\
\hline Tanjakan & 37,49 \\
\hline Akselerasi & 19,23 \\
\hline
\end{tabular}

\section{METODE PENELITIAN}

\section{Permodelan Baterai}

Penelitian ini menggunakan 8 buah baterai yang dirangkai seri-paralel yaitu 4 baterai diseri kemudian diparalel. Kapasitas keseluruhan baterai adalah tegangan 48 V dan kapasitas 140 Ah. Sedangkan masing-masing baterai mempunyai spesifikasi seperti pada Tabel 1 .

\section{Permodelan Bidirectional DC-DC Converter}

Converter digunakan untuk menaikkan tegangan DC baterai yaitu $48 \mathrm{~V}$ menjadi tegangan nominal motor yaitu 240 V. Spesifikasi dari komponen bidirectional $D C-D C$ converter adalah $L=1600 \mu \mathrm{H}, C_{H}=470 \mu \mathrm{F}, C_{L}=470 \mu \mathrm{F}$, $f_{s w}=20 \mathrm{Khz}$. Gambar 1. adalah rangkaian dari bidirectional DC-DC converter [10].

\section{Pemodelan Beban Mobil Listrik}

Mobil listrik yang digunakan dimodelkan dengan sebuah motor DC dengan daya $5 \mathrm{hp}$, tegangan $240 \mathrm{~V}$, 
putaran motor $1750 \mathrm{rpm}$, dan tegangan medan $150 \mathrm{~V}$. Masukan torsi motor (TL) ialah hasil perhitungan antara daya mekanik dibagi dengan kecepatan sudut motor listrik. Motor DC yang digunakan dimodelkan seperti pada Gambar 2.

Mobil listrik yang digunakan dalam permodelan didapatkan dengan spesifikasi pada Tabel 2. Dari data spesifikasi kendaraan pada Tabel 2. maka didapatkan tiga nilai kondisi daya mekanik mobil listrik yang akan digunakan dalam pengujian sistem. Hasil perhitungan dari rumus daya mekanik pada tiga kondisi mobil listrik ditampilkan oleh Tabel 3.

Hasil daya mekanik tersebut digunakan untuk menghitung torsi motor listrik. Hasil perhitungan torsi motor listrik seperti pada Tabel 4.

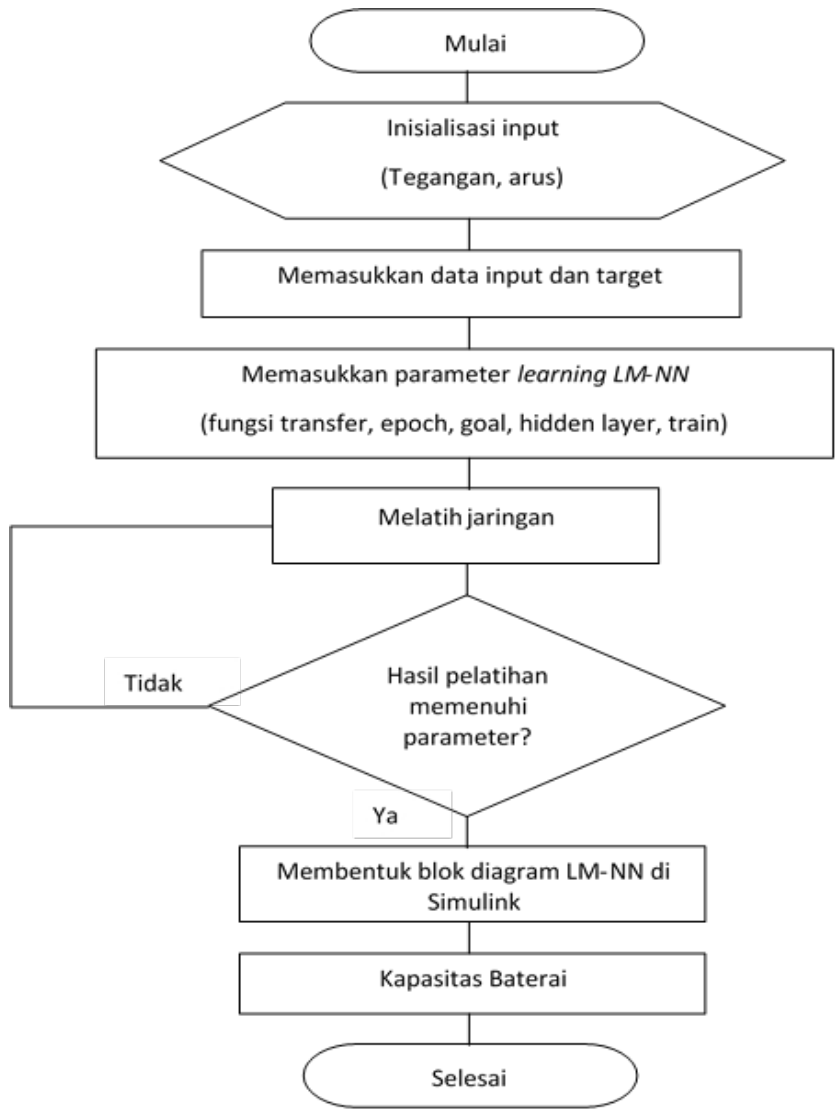

Gambar 3. Diagram alur sistem

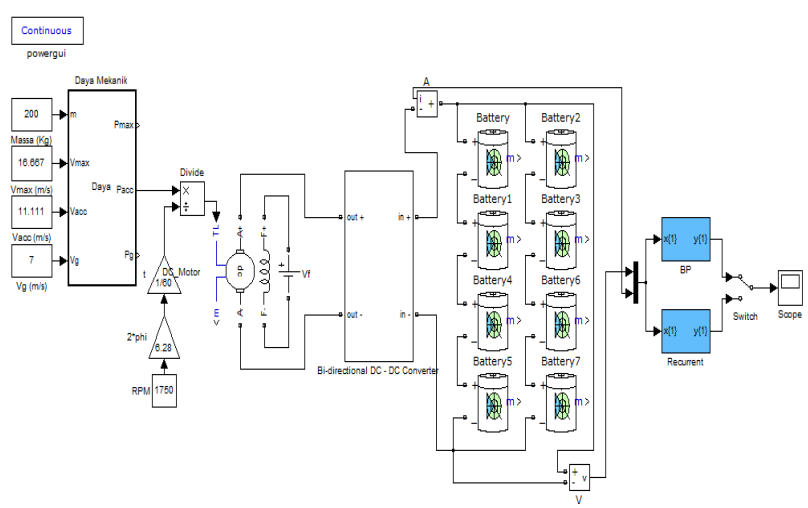

Gambar 4. Model peramalan kapasitas baterai

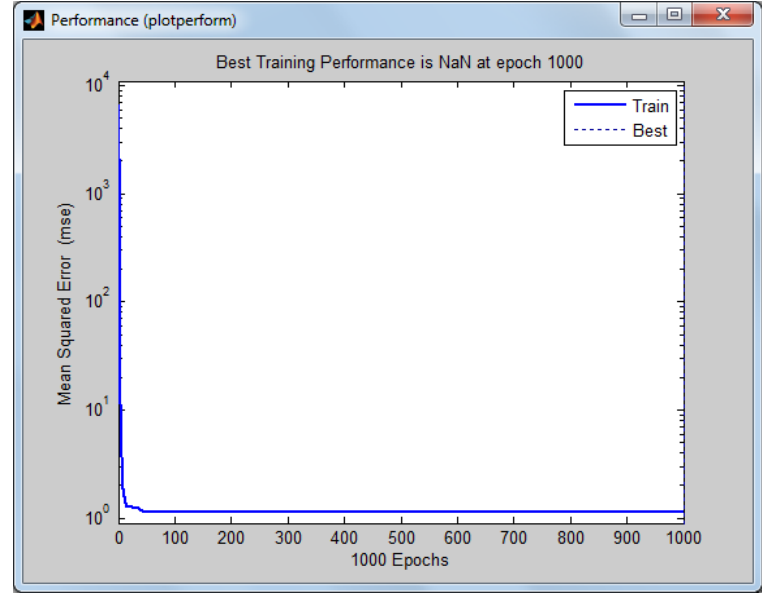

Gambar 5. Hasil performance backpropagation

\section{Diagram Alur Penelitian}

Pembuatan simulasi peramalan kapasitas baterai mobil listrik menggunakan levenberg marquardt neural network, proses pembuatan simulasinya dirancang sesuai dengan diagram alur yang ada pada Gambar 3 .

\section{HASIL PENELITIAN}

Secara keseluruhan rangkaian simulasi peramalan kapasitas baterai lead acid pada mobil listrik ditunjukkan oleh Gambar 4. Hasil training data menggunakan backpropagation levenberg marquardt menunjukkan hasil berhenti pada 1000 iterasi. Performance yang dihasilkan bernilai 1,15. Performance dari pelatihan jaringan ditunjukkan oleh Gambar 5.

Pada Gambar 6. terlihat bahwa output dengan target memiliki korelasi (R) sebesar 0,99997 atau hampir bernilai 1. Hal ini menunjukkan hasil yang cukup baik untuk kecocokkan output jaringan terhadap target, meskipun nantinya hasil peramalan tidak akan sama persis dengan nilai target. Output jaringan untuk data pelatihan mempunyai persamaan regresi Output $=1 \times$ target $+0,005$.

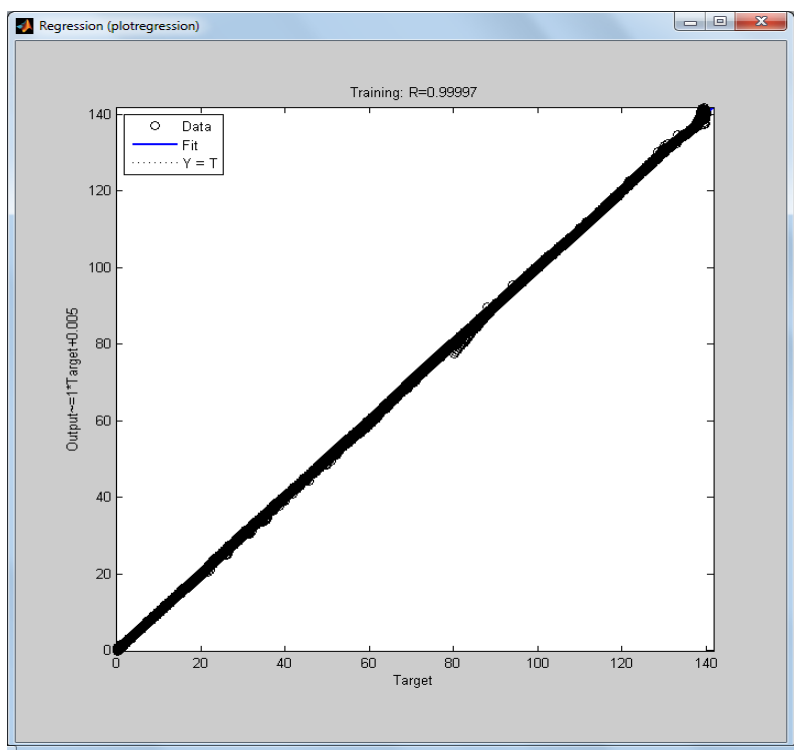

Gambar 6. Tampilan plot regression backpropagation 


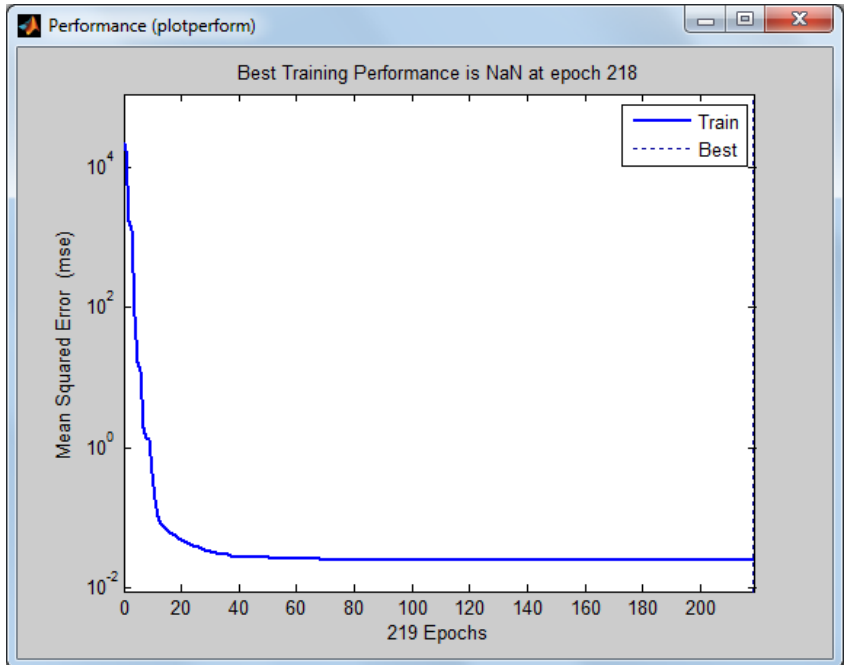

Gambar 7. Tampilan plot performance recurrent

Sedangkan hasil training data menggunakan recurrent neural network menunjukkan hasil berhenti pada parameter mu pada nilai 1 x $10^{11}$, dengan iterasi sebanyak 209 kali menghasilkan nilai performance 0,00246 . Performance dari hasil pelatihan data menggunakan recurrent neural network ditunjukkan oleh Gambar 7.

Pada Gambar 8. dapat diketahui bahwa output dan target memiliki korelasi (R) sebesar 0,99999. Dimana hasilnya lebih kecil dari regression pada backpropagation. Output jaringan untuk data pelatihan mempunyai persamaan regresi Output $=1 \times$ target $+0,0011$.

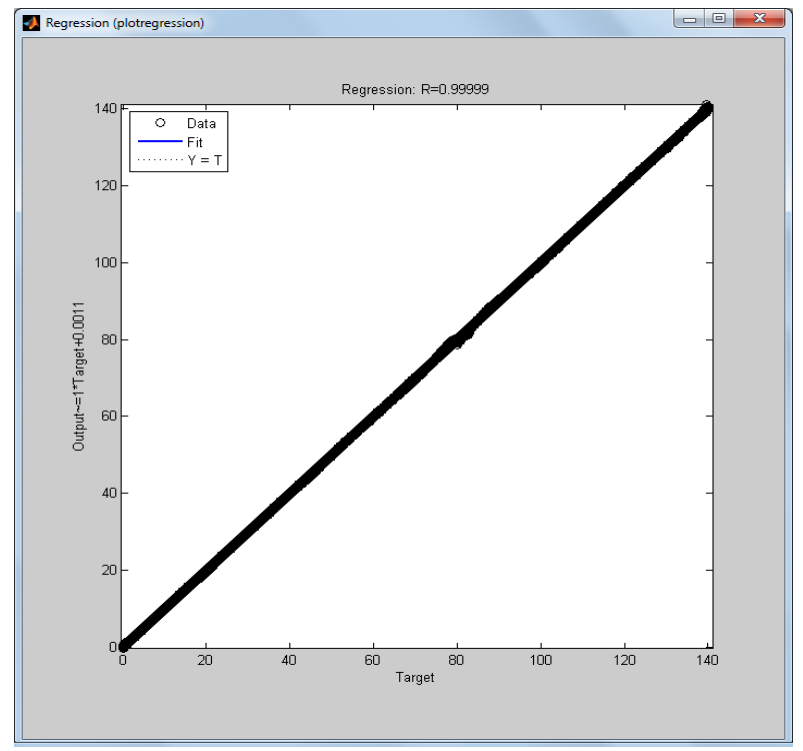

Gambar 8. Tampilan regression recurrent

Tabel 5. Peramalan kapasitas baterai

\begin{tabular}{ccccc}
\hline \multirow{2}{*}{ Kecepatan } & \multirow{2}{*}{$\begin{array}{c}\text { Waktu } \\
\text { habis } \\
\text { (jam) }\end{array}$} & \multicolumn{3}{c}{ Sisa kapasitas setelah 10 menit } \\
\cline { 3 - 5 } & & Recurren & Backpropa & Target \\
& & $t$ LM & gation & \\
\hline Maksimum & 1,09 & 113,349 & 112,554 & 113,214 \\
\hline Akselerasi & 0,88 & 118,546 & 116,314 & 118,766 \\
\hline Tanjakan & 0,64 & 103,570 & 103,108 & 103,55 \\
\hline
\end{tabular}

Sisa kapasitas setelah 30 menit (Ah)

Sisa kapasitas setelah 45 menit (Ah)

Recurren Backpro Target Recurren Backpropa Target

\begin{tabular}{cccccc}
$t L M$ & pagation & \multicolumn{3}{c}{$t$ LM } & gation \\
\hline 60,5607 & 61,0040 & 59,642 & 21,625 & 21,744 & 19,464 \\
\hline 76,1249 & 74,7005 & 76,299 & 43,489 & 44,308 & 44,449 \\
\hline 30,6395 & 30,5725 & 30,65 & 0 & 0 & 0 \\
\hline
\end{tabular}

\section{Hasil Peramalan Kapasitas Baterai}

Hasil peramalan kapasitas baterai menggunakan backpropagation dan recurrent neural network ditunjukkan oleh Gambar 9. Saat beban dengan kecepatan akselerasi maka hasil peramalan kapasitas baterai yaitu 140 Ah akan habis dalam waktu 1,09 jam. Sedangkan pada saat beban kecepatan maksimum maka hasil peramalan kapasitas baterai akan habis dalam 0,88 jam dan saat beban kecepatan tanjakan maka diramalkan kapasitas baterai akan habis dalam waktu 0,64 jam.

Pengujian selanjutnya dengan menjalankan simulasi dalam 3 waktu yang berbeda yaitu 15 menit, 30 menit, dan 45 menit. Maka sisa kapasitas yang dapat digunakan pada tiga waktu tersebut dicatat dan dibandingkan antara metode backpropagation dengan recurrent sehingga didapatkan nilai sisa kapasitas baterai dari kedua metode tersebut. Kemudian dibandingkan dengan nilai perhitungan sisa kapasitas diketahui bahwa metode terbaik dari kedua metode adalah metode recurrent. Hal ini karena nilai peramalan sisa kapasitas baterai dari metode recurrent mendekati nilai target. Hasil perbandingan ditunjukkan oleh Tabel 5.

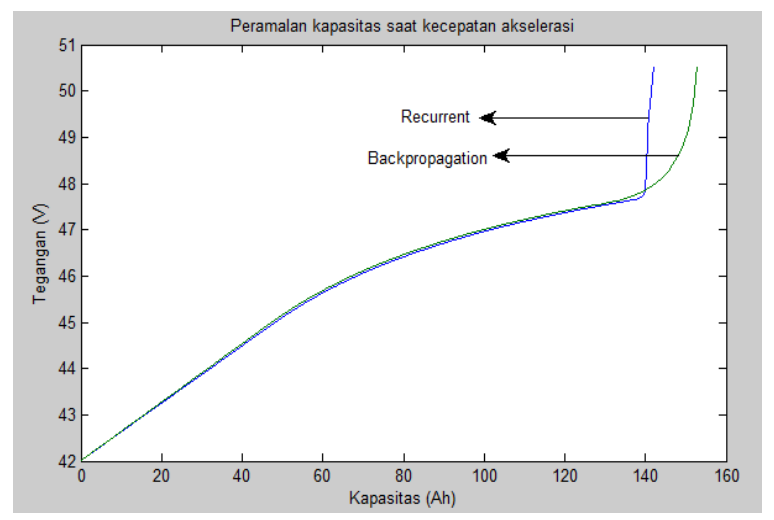

(a)

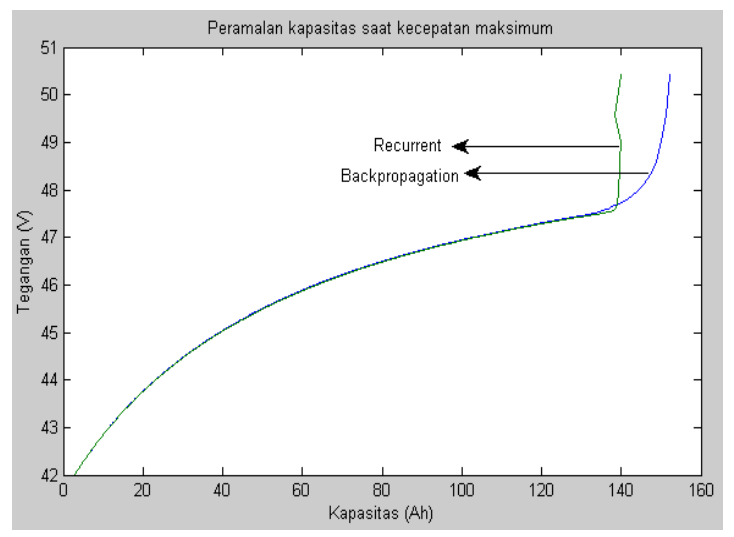

(b) 


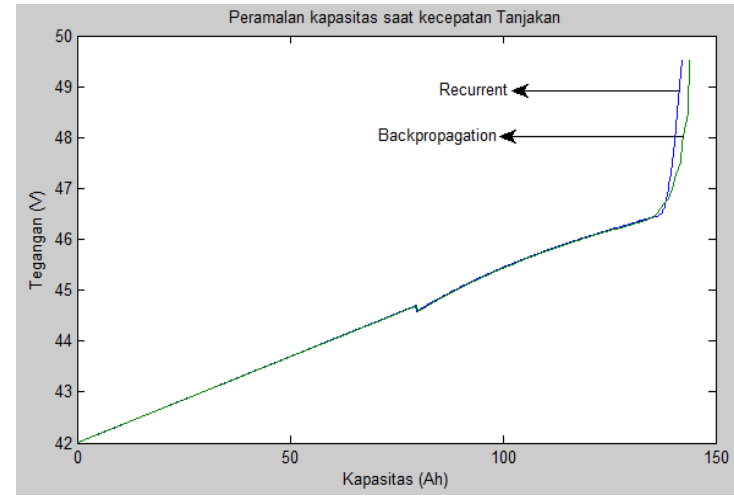

(c)

Gambar 9. Grafik peramalan kapasitas baterai (a) Saat akselerasi awal, (b) Saat kecepatan maksimum, dan (c) Saat kecepatan tanjakan.

\section{KESIMPULAN}

Dari hasil penelitian peramalan kapasitas baterai lead acid pada mobil listrik berbasis levenberg marquardt neural network, maka dapat diambil beberapa kesimpulan, diantaranya yaitu:

1. Perancangan peramalan kapasitas baterai lead acid pada mobil listrik berbasis levenberg marquardt ini dapat menggunakan dua buah neural network yaitu backpropagation dan recurrent.

2. Hasil peramalan kapasitas baterai yaitu 140 Ah saat kecepatan akselerasi maka akan habis dalam waktu 1,09 jam. Sedangkan pada saat kecepatan maksimum maka akan habis dalam 0,88 jam dan saat beban kecepatan tanjakan maka akan habis dalam waktu 0,64 jam.

Metode terbaik dalam meramalkan sisa kapasitas baterai adalah dengan metode recurrent neural network. Hal ini ditunjukkan salah satunya, saat menggunakan kecepatan maksimum $(16,67 \mathrm{~m} / \mathrm{s})$ hasil peramalan setelah 30 menit berjalan sisa kapasitas baterai dari backpropagation adalah $61 \mathrm{Ah}$ dan recurrent adalah 60,5 Ah sedangkan targetnya adalah 59,6 Ah.

\section{DAFTAR PUSTAKA}

[1] Wai, C. K., Rong, Y. Y. \& Morris, S., 2015. Simulation of a Distance Estimator for Battery Electric Vehicle. Alexandria Engineering Journal. Vol. 54: 359 - 371.

[2] Cubon, P., Radvan, R. \& Vavrus, V., 2015. Optimization Source Structure of Electric Vehicle Using Calculation of Energy Consumption in Matlab GUI. Mechatronics. Vol. 13(2) : 156 - 161.

[3] Al-Atas, Husin Mustafa. 2015. Pengembangan Model Baterai Timbal Asam Berbasis RBFNN (Radial Basic Function Neural Network). Universitas Jember.

[4] Agarwal, Vipul \& Rajan, Ritu. 2013. Modeling of Electric Vehicle: State of Art. MIT International Journal of Electrical and Instrumentation Engineering. Vol. 3(1): 24-28.

[5] S., Anda Andycka \& Brahmana, K., 2014. Pembuatan Sumber Tenaga Listrik Cadangan Menggunakan Solar Cell, Baterai dan Inverter Untuk Keperluan Rumah Tangga. Universitas Sumatra Utara.
[6] Yang, Xiyun., Jiang, Feifei., \& Wu, Xiaoning., 2013. Prediction of Lead Acid Storage Battery's Remaining Capacity Based on LM-BP Neural Network. Chinese Control and Decision Conference (CCDC). Vol 25: 1908 - 1912.

[7] Oktaorora, A., Amaliah, B. \& Saikhu, A. 2011. Penentuan Jenis Produk Kosmetik Pilihan Berdasarkan Faktor Usia Dan Warna Kulit Menggunakan Metode Jaringan Syaraf Tiruan. Institut Teknologi Sepuluh November.

[8] Adianshar, Ammar. 2014. Penerapan Recurrent Neural Network Dalam Identifikasi Tulisan Tangan Huruf Jepang Jenis Katakana. Universitas Sumatra Utara.

[9] Kurniawan, Alif. 2012. Peramalan Awal Musim Hujan Menggunakan Jaringan Syaraf Tiruan Backpropagation Levenberg - Marquardt. Institut Pertanian Bogor.

[10] Pany, Premananda., R.K. Singh., R.K. Tripathi. 2011. Bidirectional DC-DC converter fed drive for electric vehicle system. Intenational Journal of Engineering, science and Technology. Vol. 3(3): $101-110$. 